\title{
OPEN Author Correction: Label-free detection of nanoparticles using depth scanning correlation interferometric microscopy
}

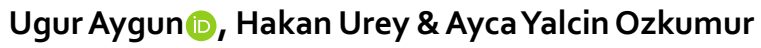

Correction to: Scientific Reports https://doi.org/10.1038/s41598-019-45439-x, published online 21 June 2019

The Acknowledgements section in this Article is incomplete.

"The authors would like to thank Dr. Baris Yagci (Koç University-KUYTAM) for SEM analysis, Prof. Utkan Demirci (BAMM Lab, Stanford University) for kindly providing exosome samples and Prof. M. Selim Ünlü (Boston University) for introduction to IRIS technology and helpful discussions. This work has been supported by TUBITAK Grants 113E643 and 115E260. The authors gratefully acknowledge use of the facilities of Koç University Research Center for Translational Medicine (KUTTAM)".

should read:

“The authors would like to thank Dr. Baris Yagci (Koç University-KUYTAM) for SEM analysis, Prof. Utkan Demirci (BAMM Lab, Stanford University) for kindly providing exosome samples and Prof. M. Selim Ünlü (Boston University) for introduction to IRIS technology and helpful discussions. This work has been supported by TUBITAK Grants 113E643 and 115E260. Ayca Yalcin Ozkumur received partial funding from the European Union's Horizon 2020 research and innovation programme under grant agreement No 766466. The authors gratefully acknowledge use of the facilities of Koç University Research Center for Translational Medicine (KUTTAM)".

(c) (i) Open Access This article is licensed under a Creative Commons Attribution 4.0 International License, which permits use, sharing, adaptation, distribution and reproduction in any medium or format, as long as you give appropriate credit to the original author(s) and the source, provide a link to the Creative Commons license, and indicate if changes were made. The images or other third party material in this article are included in the article's Creative Commons license, unless indicated otherwise in a credit line to the material. If material is not included in the article's Creative Commons license and your intended use is not permitted by statutory regulation or exceeds the permitted use, you will need to obtain permission directly from the copyright holder. To view a copy of this license, visit http://creativecommons.org/licenses/by/4.0/.

(C) The Author(s) 2019 